\title{
Efektivitas ice breaking dalam mengurangi kejenuhan peserta didik mempelajari Bahasa Arab
}

\author{
Desmidar
}

Program Pascasarjana Universitas Muhammadiyah Sumatera Barat, Indonesia

Email:desmidaroke@gmail.com

Mahyudin Ritonga

Universitas Muhammadiyah Sumatera Barat, Indonesia

Email: mahyudinritonga@gmail.com

Syaflin Halim

Universitas Muhammadiyah Sumatera Barat, Indonesia

Email:syaflin_h@gmail.com

\begin{abstract}
Static learning conditions are seen as disproportionate because it causes learners to feel burdened, bored and saturated. Learning saturation is defined as physical, emotional, and mental fatigue experienced by students characterized by decreased motivation and interest in student learning, which can result in decreased student learning achievement. The saturation of learning occurs because the learning process of students is done continuously and for a long time but does not get success. The purpose of this study is to test the effectiveness of ice breaking to reduce the saturation of students' learning. The research uses quantitative approach with quasi experimental design non equivalent pretest post test control group. The research sample was grade VIII.1 MTsN 2 Pasaman students, which is 41 people. The results showed that there was a decrease in
\end{abstract}


the average score of student saturation of 19.07. A significant change in learning saturation score of $15.31 \%$. Recommendations to teachers in order to creatively create an interesting and fun learning atmosphere, one of which is by applying ice breaking games in the learning process so that the learning process becomes more optimal.

Keywords: efectivity; ice breaking; learning process

\section{Abstrak}

Kondisi pembelajaran yang statis dipandang tidak proporsional karena menyebabkan peserta didik merasa terbebani, bosan dan jenuh. Kejenuhan belajar didefinisikan sebagai kelelahan fisik, emosional, dan mental yang dialami oleh siswa yang ditandai dengan penurunan motivasi dan minat peserta didik dalam pembelajaran, motivasi dan minat yang rendah dapat mengakibatkan penurunan prestasi belajar siswa. Kejenuhan belajar terjadi karena proses belajar siswa dilakukan secara terus menerus dan untuk waktu yang lama namun tidak mendapatkan kesuksesan. Tujuan dari penelitian ini adalah untuk menguji efektivitas ice breaking dalam mengurangi kejenuhan peserta didik pada saat pembelajaran. Penelitian ini menggunakan pendekatan kuantitatif dengan desain eksperimen semu. Sampel penelitian tersebut adalah peserta didik kelas VIII.1 MTs Negeri 2 Pasaman, yaitu 41 orang. Hasil penelitian menunjukkan bahwa ada penurunan skor rata-rata kejenuhan siswa sebesar 19,07. Pembelajaran dengan menggunakan ice breaking membuat proses pembelajaran mengalami peningkatan kualitas dan hilangnya kejenuhan peserta didik sebesar 15,31\%. Rekomendasi kepada guru agar kreatif menciptakan suasana belajar yang menarik dan menyenangkan, salah satunya dengan menerapkan permainan ice breaking dalam proses pembelajaran agar proses pembelajaran menjadi lebih optimal.

Kata Kunci: Efektivitas, Ice Breaking, Proses Pembelajaran

\section{Pendahuluan}

Di sekolah siswa diwajibkan untuk mengikuti semua mata pelajaran yang ada sampai jam pulang sekolah yang telah ditetapkan. Selain itu, selama proses pembelajaran berlangsung siswa diharuskan untuk membaca, mendengar, memahami dan mencatat semua materi yang diberikan guru. Terdapat berbagai peraturan dan tuntutan yang ditetapkan guru dan sekolah (Yusuf et al., 2020), maka tidak jarang jika siswa merasa jenuh dan menjadi tidak fokus dengan 
pelajaran yang diberikan (Sieberer-Nagler, 2016). Perilaku jenuh dalam belajar merupakan salah satu jenis gangguan psikologis akibat stress belajar yang muncul dihampir semua lingkup sekolah yang selalu mengadakan kontak seperti siswa dengan guru (Deasy et al., 2014)coping processes (Ways of Coping Questionnaire.

Kejenuhan merupakan respons psikologis terhadap stres kerja yang ditandai dengan kelelahan emosional, depersonalisasi, dan kurangnya perasaan pencapaian pribadi (Halbesleben \& Buckley, 2004). Kejenuhan belajar dapat diartikan sebagai kelelahan fisik, emosi, dan mental yang dialami oleh siswa, yang ditandai dengan menurunnya motivasi dan minat siswa untuk belajar, timbulnya rasa malas yang berat, dan menurunnya prestasi belajar siswa (Mailita et al., 2016). Kejenuhan belajar dikaitkan dengan keadaan dimana siswa merasakan kelelahan secara emosional, tidak efisien dan mudah marah (Wullur \& Werang, 2020). Perasaan tersebut disebabkan karena siswa merasa kegiatan belajar yang dilakukan selama ini merupakan sesuatu hal yang sia-sia. Siswa melakukan kegiatan belajar akan tetapi tidak mendapatkan hasil yang baik disebabkan kejenuhan belajar yang mereka alami (Licorish et al., 2018).

Penyebab utama kejenuhan belajar yang paling umum adalah keletihan yang melanda peserta didik (Jandri] et al., 2020), keletihan dapat membuat peserta didik merasa bosan terhadap situasi yang ada. Kemudian tugas yang banyak juga menyebabkan munculnya perasaan tertekan yang dialami siswa, sehingga secara emosional membuat siswa mengalami kejenuhan yang berakibatkan pada penurunan kualitias belajar. Keletihan yang dialami oleh siswa, baik letih secara psikologis dan letih secara fisik menjadikan siswa tidak semangat belajar, hilangnya motivasi dan menurunnya tingkat keyakinan diri dalam belajar (Islam et al., 2018). Selain itu kejenuhan belajar yang dialami siswa dapat disebabkan oleh: (1) Work overload, yaitu siswa mendapatkan tugas yang banyak, sehingga siswa merasa sangat terbebani dengan tugas yang diberikan; (2) Lack of control, yaitu siswa merasa bahwa penbelajaran yang diberikan kurang menarik, kemudian dalam hal ini guru juga kurang memberikan kesempatan kepada siswa untuk aktif selaama proses pembelajaran berlangsung; (3) Insufficient reward, yaitu siswa merasa guru kurang menghargai usaha yang dilakukan dan prestasi yang telah dicapai; (4) Breakdown incommunity, yaitu siswa merasa kurang nyaman membangun hubungan social di sekolah, baik dengan guru maupun dengan teman di sekolah; (5) Absence infairness, yaitu bayangan orang tua terhadap nilai yang tinggi merupakan prestasi terbaik. Siswa dituntut untuk memiliki nilai yang tinggi. Hal tersebut juga merupakan salah satu 
penyebab kejenuhan belajar siswa; (6) Conflicting value, yaitu siswa mengalami shock culture antara nilai-nilai yang diajarkan di sekolah dengan nilai-nilai yang diajarkan di rumah (Slivar, 2001).

Salah satu mata pelajaran yang membuat siswa MTsN merasa jenuh dalam belajar yaitu mata pelajaran Bahasa Arab. Bahasa Arab merupakan mata pelajaran yang sulit menurut sebagian besar peserta didik, baik dalam tingkat satuan pendidikan dasar hingga tingkat pendidikan tinggi, baik disekolah formal maupun di pendidikan non formal. Hal tersebut tidak hanya dirasakan oleh siswa, tetapi masyarakat pada umumnya juga menganggap bahwa Bahasa Arab sangat sulit (Ansyah et al., 2020).

Permasalahan yang dihadapi dalam pelajaran Bahasa Arab yaitu permasalahan kebahasaan yang rumit, seperti siswa mengalami kebingungan menerjemahkan kata dalam teks, pengucapan huruf yang sukar (Khaira et al., 2021), serta mengalami kesulitan dalam praktek percakapan. Selanjutnya permasalahan nonkebahasaan yaitu seperti motivasi dan minat belajar siswa yang rendah (Ritonga et al., 2021). Kejenuhan belajar yang dialami peserta didik ditandai dengan peserta didik kurang antusiasme dan kurang bersemangat dalam mengikuti pelajaran di kelas. Peserta didik cenderung gaduh, tidak memperhatikan guru ketika sedang berlangsung KBM (Kegiatan Belajar Mengajar), tidak pernah mencatat materi, mengabaikan tugas yang diberikan guru, melamun, mengobrol dengan teman sebangku, tidur saat proses belajar mengajar dan tidak jarang juga peserta didik membolos atau tidak masuk sekolah dengan berbagai alasan lain untuk menghindari kegiatan KBM (Sari et al., 2019).

Kejenuhan dapat menghilangkan motivasi belajar siswa. Apabila kejenuhan belajar tidak ditangani dengan baik maka akan berdampak buruk pada proses dan hasil belajar siswa. Dengan demikian kejenuhan belajar yang dirasakan peserta didik merupakan permasalahan yang perlu ditangani dan ditindaklanjuti supaya peserta didik dapat mengembangkan perilaku jangka panjang dan mencapai kesuksesan dalam belajar guna meraih cita-cita yang diinginkan. Beberapa cara yang dapat dilakukan untuk mengatasi kejenuhan belajar yaitu: 1) belajar dengan cara atau metode yang bervariasi; 2) mengadakan perubahan fisik di ruang belajar; 3) menciptakan situasi baru di ruang belajar; 4) melakukan aktivitas rekreasi dan hiburan; dan 5) menghindari terjadinya suasana belajar yang mengakibatkan ketegangan mental (Kintu et al., 2017). Selain itu untuk mengurangi tingkat kejenuhan dapat dilakukan kegiatan ice breaking dalam proses pembelajaran (Hutasoit \& Tambunan, 2018; Farwati et al., 2018). 
Ice breaking merupakan sentuhan aktivitas yang dapat digunakan untuk memecahkan kebekuan, kekalutan, kejemuan dan kejenuhan suasana sehingga menjadi mencair (Yeganehpour, 2017). Penerapan ice breaking dalam pembelajaran memungkinkan peserta didik kembali pada kondisi yang semangat dan bergairah dalam belajar, serta memiliki motivasi belajar yang lebih baik. Permainan ice breaking sangat baik diterapkan dalam pembelajaran, karena akan menghilangkan kebosanan, kejemuan, kecemasan, dan keletihan peserta didik. Selain itu banyak sekali manfaat dari diterapkan ice breaking dalam pembelajaran, seperti: a) melatih peserta untuk mampu berfikir luas, sistematis dan kreatif; b) melatih siswa untuk mampu berinteraksi dalam kelompok dan bekerjasama dalam satu tim; c) meningkatkan rasa percaya diri peserta didik; d) melatih konsentrasi, berani bertindak dan tidak takut salah; e) merekatkan hubungan interpersonal yang renggang; f) melatih peserta didik untuk menghargai orang lain; g) memantapkan konsep diri; (h) melatih jiwa kepemimpinan; dan i) melatih mengambil keputusan dan tindakan (Fanani, 2017).

\section{Metode}

Penelitian ini menggunakan pendekatan kuantitatif. Pendekatan kuantitatif dalam penelitian ini digunakan untuk menguji efektivitas permainan ice breaking untuk mengurangi kejenuhan belajar siswa. Metode penelitian yang digunakan yaitu metode quasi-eksperiment dengan desain penelitian yaitu Nonequivalent Control Group Design. Sampel penelitian yaitu siswa kelas VIII.1 MTsN 2 Pasaman, Sumatera Barat. Pemilihan sampel penelitian yaitu dengan menggunakan purposive sampling. Purposive sampling adalah teknik penentuan sampel dengan pertimbangan tertentu (Tongco, 2007). Kriteria yang digunakan untuk penentuan sampel yaitu kelas yang memiliki tingkat kejenuhan belajar Bahasa Arab yang tinggi.

Teknik pengumpulan data dilakukan dengan menggunakan instrument. Instrument yang digunakan dalam penelitian ini adalah angket kejenuhan belajar Bahasa Arab. Butir-butir pernyataan pada instrumen disusun berdasarkan indikator-indikator yang tercakup dalam konsep kejenuhan (burnout) oleh Maslach \& Jackson berpendapat bahwa terdapat tiga aspek dalam kejenuhan belajar, yaituemotional exhaustion, depersonalization, dan personal accomplishment (Maslach \& Jackson, 1981). Skala ini disusun dalam bentuk kalimat pernyataan (positif dan negatif) dengan pilihan jawaban yang tersedia yaitu Sangat Sesuai (SS), Sesuai (S), Netral (N), Tidak Sesuai (TS), dan Sangat Tidak Sesuai (STS). 
Hasil penelitian ini dianalisis menggunakan uji mann whitney (u-test). Uji ini merupakan uji yang digunakan untuk menguji hipotesis dua sampel independen (two independent sample tests).

\section{Hasil dan Pembahasan}

Berdasarkan penelitian mengenai efektifitas ice breaking untuk mengurangi kejenuhan belajar siswa, berikut ini disajikan hasil penelitian yang meliputi: (a) profil kejenuhan belajar siswa MTsN 2 Pasaman tahun ajaran 2020/2021; (b) profil kejenuhan belajar siswa kelas eksperimen dan kelas kontol sebelum diberikan ice breaking (pretest); (c) pelaksanaan ice breaking dalam proses pembelajaran bahasa arab untuk mengurangi kejenuhan belajar siswa kelas eksperimen; (d) profil kejenuhan belajar siswa kelas eksperimen setelah diberikan ice breaking (posttest); dan (e) efektivitas penggunaan ice breaking untuk mengurangi kejenuhan belajar siswa.

\section{Profil Kejenuhan Belajar Siswa MTsN 2 Pasaman Tahun Ajaran 2020/2021}

Berdasarkan hasil dari pengolahan angket kejenuhan belajar yang telah dilakukan yang dilakukan kepada 82 orang siswa kelas VIII menggunakan skala kejenuhan belajar sebanyak 56 item, diperoleh profil umum siswa kelas VIII MTsN 2 Pasaman Tahun Ajaran 2020/2021 menunjukkan skor rata-rata 139, 35 dan standard deviasi sebesar 41,237. Berikut ini tingkat kejenuhan belajar siswa berdasarkan kategori tinggi, sedang, dan rendah.

Tabel 1. Gambaran Distribusi Frekuensi Kejenuhan Belajar Siswa pada Pelajaran Bahasa Arab

\begin{tabular}{ccccc}
\hline No & Kategori & Interval Skor & F & Persentase \\
\hline 1 & Tinggi & $>181$ & 14 & 17.1 \\
\hline 2 & Sedang & $98-181$ & 26 & 68.3 \\
\hline 3 & Rendah & $<98$ & 12 & 14.6 \\
\hline & & & 82 & 100.00 \\
\hline
\end{tabular}

Berdasarkan Tabel 1. Tersebut diketahui bahwa tingkat kejenuhan belajar Bahasa Arab siswa kelas VIII berada pada kategori sedang, hal ini berarti beberapa siswa masih terlihat kelelahan, lesu, bosan dan mengantuk 
ketika mengikuti proses pembelajaran Bahasa Arab, sulit untuk berkonsentrasi, menarik diri dari lingkungan, serta pesimis akan kemampuan diri yang dimiliki.

Kejenuhan merupakan respons psikologis terhadap stres kerja yang ditandai dengan kelelahan emosional, depersonalisasi, dan kurangnya perasaan pencapaian pribadi (Halbesleben \& Buckley, 2004; Di Monte et al., 2020). Perilaku jenuh dalam belajar merupakan salah satu jenis gangguan psikologis akibat stress belajar yang muncul dihampir semua lingkup sekolah yang selalu mengadakan kontak seperti siswa dengan guru (Khairunnas et al., 2021; Sartika et al., 2020; Alim et al., 2020). Kejenuhan belajar juga dapat diartikan sebagai kelelahan fisik, emosi, dan mental yang dialami oleh peserta didik, yang ditandai dengan menurunnya motivasi dan minat siswa untuk belajar, timbulnya rasa malas yang berat, dan menurunnya prestasi belajar siswa (Agustina, 2021).

Kejenuhan belajar mempunyai tanda-tanda atau gejala-gejala yang sering dialami yaitu timbulnya rasa enggan, malas, lesu dan tidak bergairah untuk belajar Kejenuhan belajar yang dialami peserta didik ditandai dengan kurang aktif dan kurang antusiasme siswa dalam mengikuti pelajaran di kelas. Peserta didik cenderung gaduh, tidak pernah mencatat materi, melamun, mengobrol dengan teman sebangku, tidur saat proses belajar mengajar dan sering tidak masuk sekolah dengan alasan yang tidak jelas.

\section{Profil Kejenuhan Belajar Siswa Kelas Eksperimen dan Kelas Kontol Sebelum Diberikan Ice Breaking (Pretest)}

Berdasarkan hasil penelitian pada kelas eksperimen (VIII.1) yang berjumlah 41 orang diketahui bahwa kejenuhan belajar siswa kelas VIII.1 sebelum diberikan perlakuan (pretest) tahun ajaran 2020/2021 menunjukkan rata-rata skor yaitu 141,1 dengan Standar Deviasi yaitu 45,11. Berikut ini tingkat kejenuhan belajar siswa berdasarkan kategori tinggi, sedang, dan rendah.

Tabel 2. Profil Pretest Kejenuhan Belajar Bahasa Arab Siswa Kelas Eksperimen

\begin{tabular}{|c|c|c|c|c|}
\hline No & Kategori & Interval Skor & $\mathrm{F}$ & Persentase \\
\hline 1 & Tinggi & $>186$ & 6 & $14,63 \%$ \\
\hline 2 & Sedang & $94-186$ & 30 & $73,17 \%$ \\
\hline 3 & Rendah & $<94$ & 5 & $12,2 \%$ \\
\hline \multicolumn{3}{|c|}{ Jumlah } & 41 & $100 \%$ \\
\hline
\end{tabular}


Selanjutnya berdasarkan hasil penelitian pada kelas control (VIII.2) yang berjumlah 41 orang, diketahui rata-rata skor kejenuhan belajar siswa kelas VIII.2 yaitu 137,6 dengan standar deviasi yaitu 37,65. Berikut ini tingkat kejenuhan belajar siswa berdasarkan kategori tinggi, sedang, dan rendah.

Tabel 3. Profil Pretest Kejenuhan Belajar Bahasa Arab Siswa Kelas Kontrol

\begin{tabular}{|c|c|c|c|c|}
\hline No & Kategori & Interval Skor & $\mathbf{F}$ & Persentase \\
\hline 1 & Tinggi & $>176$ & 7 & $17,07 \%$ \\
\hline 2 & Sedang & 94-175 & 29 & $70,73 \%$ \\
\hline 3 & Rendah & $<94$ & 5 & $12,2 \%$ \\
\hline \multicolumn{3}{|c|}{ Jumlah } & 41 & $100 \%$ \\
\hline
\end{tabular}

Berdasarkan hasil pretest diketahui bahwa, tingkat kejenuhan belajar siswa kelas eksperimen dan kelas control yaitu berada pada kategori sedang, artinya beberapa siswa merasakan kejenuhan dalam belajar Bahasa Arab. Rata-rata kejenuhan siswa kelas eksperimen terlihat lebih tinggi dibandingkan dengan kelas control, akan tetapi nilai ini tidak signifikan berbeda setelah dilakukan dengan uji statistic nonparametric Mann Whitney U Test dengan perolehan Asymp. Sig (2-tailed) yaitu 0.842 .

Kejenuhan belajar yang dialami siswa ditandai dengan timbulnya rasa enggan, malas, lesu dan tidak bergairah siswa untuk mengikuti proses pembelajaran, siswa cenderung gaduh, tidak memperhatikan guru ketika sedang berlangsung KBM (Kegiatan Belajar Mengajar), tidak pernah mencatat materi, mengabaikan tugas yang diberikan guru, melamun, mengobrol dengan teman sebangku, tidur saat proses belajar mengajar dan tidak jarang juga peserta didik membolos atau tidak masuk sekolah dengan berbagai alasan lain untuk menghindari kegiatan KBM (Rachim, 2020).

Kejenuhan belajar yang dialami siswa ditandai dengan emotional exhaustion (kelelahan emosi), depersonalisasi (depersonalization), dan pesimis akan pencapaian individual (personal accomplishment) (Maslach \& Jackson, 1981). Emotional exhaustion (kelelahan emosi) terjadi karena beban kerja yang terlalu berat. Dalam hal ini, beban kerja yang dialami siswa di sekolah diantaranya yaitu tingkat kesulitan materi pelajaran serta tugas yang diberikan kepada siswa melebihi kemampuan siswa. Kemudian kuantitas atau jumlah tugas yang dikerjakan siswa terlalu banyak, sehingga siswa merasakan kelelahan secara fisik dan emosi. Hal ini yang menyebabkan siswa menjadi tidak bersemangat dan 
sangat kesulitan memahami materi pelajaran yang dijelaskan. Kelelahan emosi yang terjadi pada siswa berhubungan dengan perasaan pribadi dan terkurasnya sumber-sumber emosional yang ditandai dengan rasa tidak berdaya, stress ataupun depresi. Kelelahan emosi yang dialami siswa berasal dari aspek yang berbeda-beda, seperti: siswa sering merasa gagal dalam belajar, merasa bersalah dan menyalahkan, merasa dikejar-kejar waktu selama prose pembelajaran, mudah cemas, mudah marah, mudah kehilangan kendali diri dalam belajar, dan mengalami ketakutann berlebih dalam proses pembelajaran.

Depersonalizatio (depersonalisasi) diartikan sebagai perasaan dan sikap negative dan sinis terhadap orang lain. Depersonalisasi merupakan kondisi di mana proses menarik diri individu karena merasakan sinisme terhadap lingkungannya dan bermaksud menjaga jarak dari lingkungan karena takut dikecewakan oleh lingkungan sosialnya. Dengan demikian, masih banyak terdapat siswa MTsN 2 Pasaman yang merasa kekosongan dan kehampaan dalam dirinya serta menarik diri dari lingkungan sekitar, artinya masih banyak siswa yang memiliki sikap pesimis terhadap orang lain serta merasakan sinisme terhadap lingkungannya. Siswa merasa lingkungan sekitar tidak memberikan dampak yang baik bagi dirinya. Seperti siswa tidak peduli dengan temanteman disekitar, dan merasa tidak senang ketika teman membicarakan materi pelajaran dan tugas, siswa merasa tidak pantas untuk berada dalam kelompok teman-teman sepelajaran, dan lain sebagainya.

Personal accomplishment (pencapaian individual) ini adalah tahap di mana seorang individu pesimis akan kemampuan diri sendiri. Dengan kata lain depersonalisasi merupakan suatu usaha untuk memberi jarak antara diri dengan orang lain. masih banyak siswa MTsN 2 Pasaman yang mengalami penurunan pencapaian diri (low personal accomplishment) terutama pada capaian akademik. Siswa merasa pesimis dengan kemampuan diri sendiri, seperti siswa merasa gagal dalam belajar Bahasa Arab, siswa merasa tidak ada lagi peluang untuk sukses dalam belajar, siswa merasa pesimis untuk bisa dan berhasil dalam belajar Bahasa Arab, dan lain sebagainya. Menurunnya capaian diri siswa ditandai dengan adanya perasaan tidak mampu dan mengakibatkan adanya rasa kurang percaya diri dalam mengerjakan tugas yang diberikan oleh guru. Personal accomplishment dalam penelitian ini diartikan dengan adanya perasaan kurang efektif seperti kehilangan kompetensi dan kemampuan yang dimiliki. 


\section{Pelaksanaan Ice Breaking dalam Proses Pembelajaran Bahasa Arab untuk Mengurangi Kejenuhan Belajar Siswa Kelas Eksperimen}

Pelaksanaan ice breaking dalam proses pembelajaran mata pelajaran Bahasa Arab untuk kelas VIII.1 (Kelas Eksperimen) dilakukan sebanyak enam sesi, sebagai berikut.

Pertama, kegiatan ice breaking yang dilakukan berjudul "Pesan Berantai". Permainan pesan berantai disesuaikan dengan tema pelajaran yaitu Permainan Bola Kaki. Pelaksanan ice breaking yaitu dengan cara siswa dibagi menjadi 4 kelompok yang terdiri dari 5 orang siswa. Tiap anggota berbaris berputar arah membelakangi orang yang pertama. Orang pertama mendapatkan satu buah kata dalam Bahasa Arab, kemudian membisikkan kata tersebut kepada orang kedua, orang kedua membisikkan ketelinga orang ketiga dan seterusnya hingga selesai. Kelompok yang menyelesaikan permainan dengan cepat dan tepat terpilih menjadi pemenangnya.

Kedua, kegiatan ice breaking yang dilakukan berjudul "Tebak Gambar", dengan tema mengenai Permainan Bola Kaki. Pelaksanaan ice breaking yaitu dengan cara peneliti menunjukkan gambar kemudian siswa secara berebutan menyebutkan Bahasa Arab dari gambar tersebut. Ketiga, kegiatan ice breaking yang dilakukan berjudul "Tebak Gerakan". Pelaksanaan permainan yaitu dengan cara satu orang siswa diminta untuk memperagakan kerakan yang telah tentukan peneliti, seperti menendang bola. Kemudian siswa secara berebutan menyebutkan dalam Bahasa Arab gerakan tersebut. Keempat, kegiatan ice breaking berjudul "Mencocokkan Gambar". Pelaksanaannya peneliti menyediakan kertas karton besar di dalam nya terdapat beberapa gambar serta Bahasa Arabnya yang disusun secara acak. Kemudian siswa diminta untuk mencocokan gambar dengan Bahasa Arabnya. Kelima, kegiatan ice breaking yang dilaksanakan yaitu berjudul "Pesan Berantai" dengan tema profesi kedokteran. Keenam, kegiatan ice breaking yang dilaksanakan berjudul "123 Door". Pelaksanaannya siswa berhitung menggunakan Bahasa Arab, kemudian orang ke empat dan kelipatannya akan mengganti angka dengan kata "door".

Kegiatan ice breaking yang dilakukan berjalan dengan baik, tidak mengganggu kegiatan belajar dan sangat bermanfaat. Siswa sangat menyukai permainan yang diberikan, terlihat siswa sangat antusias dalam kegiatan belajar sambil bermain dengan menggunakan ice breaking. 


\section{Profil Kejenuhan Belajar Siswa Kelas Eksperimen Setelah Diberikan Ice Breaking (Posttest).}

Berdasarkan hasil pengolahan angket setelah dilakukan kegiatan ice breaking pada saat proses pembelajaran Bahasa Arab diketahui bahwa diperoleh profil kejenuhan belajar siswa kelas VIII.1 setelah diberikan perlakuan ice breaking pada mata pelajaran Bahasa Arab tahun ajaran 2020/2021 menunjukkan ratarata skor yaitu 122,76, dengan standar deviasi yaitu 31. Berikut ini tingkat kejenuhan belajar siswa berdasarkan kategori tinggi, sedang, dan rendah.

Tabel 4. Profil Pretest Kejenuhan Belajar Bahasa Arab Siswa Kelas Eksperimen

\begin{tabular}{ccccc}
\hline No & Kategori & Interval Skor & F & Persentase \\
\hline 1 & Tinggi & $>154$ & 4 & 9,75 \\
\hline 2 & Sedang & $94-153$ & 30 & $73,17 \%$ \\
\hline 3 & Rendah & $<93$ & 7 & $17,07 \%$ \\
\hline \multicolumn{7}{r}{ Jumlah } & & 41 & $100 \%$ \\
\hline
\end{tabular}

\section{Efektivitas Penggunaan Ice Breaking untuk Mengurangi Kejenuhan Belajar Siswa}

Berdasarkan hasil penelitan yang telah dilakukan, diketahui rata-rata skor kejenuhan belajar Bahasa Arab siswa sebelum diberikan intervensi ice breaking (pretest) yaitu 141,1. Kemudian rata-rata skor kejenuhan belajar Bahasa Arab siswa setelah diberikan intervensi kegiatan ice breaking (posttest) yaitu 122,76. Terdapat penurunan skor sebelum dan sesudah intervensi kegiatan ice breaking sebanyak 19,07 yaitu 15,31\%. Kemudian setelah dianalisis dengan menggunakan uji statistic nonparametric Mann Whitney U Test dengan perolehan Asymp.Sig (2-tailed) yaitu 0.044. Dengan demikian maka dapat disimpulkan bahwa kegiatan ice breaking memberikan pengaruh yang signifikan dalam menurunkan kejenuhan belajar Bahasa Arab siswa.

Pemberian ice breaking dalam bentuk kegiatan bermain, dapat meningkatkan konsentrasi siswa dalam belajar, dapat menciptakan suasana yang tidak tegang dalam berinteraksi, membosankan dalam belajar dan akan terwujud fokus perhatian dan ice breaking dalam bentuk permainan efektif meningkatkan keterampilan sosial siswa (Solihat et al., 2020; Bakhtiar, 2015). Selanjutnya permainan ice breaking sangat baik diterapkan dalam pembelajaran, 
karena akan menghilangkan kebosanan, kejemuan, kecemasan, dan keletihan peserta didik.

Selain itu, sebagaimana yang dijelaskan oleh Fanani (Fanani, 2017) bahwa ice breaking memiliki manfaat yang sangat luas, seperti: 1) Melatih peserta untuk mampu berfikir luas, sistematis dan kreatif; 2) Melatih siswa untuk mampu berinteraksi dalam kelompok dan bekerjasama dalam satu tim; 3) Meningkatkan rasa percaya diri peserta didik; 4) Melatih konsentrasi, berani bertindak dan tidak takut salah; 5) Merekatkan hubungan interpersonal yang renggang; 6) Melatih peserta didik untuk menghargai orang lain; 7) Memantapkan konsep diri; 8) Melatih jiwa kepemimpinan; 9) Melatih mengambil keputusan dan tindakan.

\section{Simpulan}

Dari uraian yang telah dijelaskan pada hasil penelitian serta pembahasan dapat dikatakan bahwa Ice breaking dapat mejadi alternatif dalam mengurangi kebosanan peserta didik pada saat pembelajaran. Poin penting ini didasarkan pada data penelitian yang membuktikan terdapat perbedaan tingkat kebosanan peserta didik yang diperlakukan sebagai kelas eksperimen dengan kebosanan peserta didik pada kelas kontrol. Kejenuhan peserta didik dalam memplajari bahasa Arab sebagaimana di MTs Negeri 2 Pasaman dapat dicarikan solusinya dengan memanfaatkan berbagai strategi yang telah teruji oleh para pakar bidang pendidikan. Dari temuan penelitian yang dijelaskan di atas kemudian direkomendasikan bahwa setiap pendidik untuk melakukan inovasi dalam pembelajaran, inovasi tersebut dapat diwujudkan dalam bentuk metode, strategi atau aspek lainnya.

\section{Daftar Pustaka}

Agustina, N. T. (2021). The Effectiveness of the Use of the Form of Jigsaw in the Reading Skill of the Islamic Middle School Shining Sedan Rembang. Tanwir Arabiyyah: Arabic as Foreign Language Journal, 1(1), 33-44. https:// doi.org/10.22219/afl.v1i1.2494

Alim, N., Ritonga, M., \& Mafardi, M. (2020). Korelasi Kegiatan Ekstrakurikuler Sanggar Al-Quran dengan Hasil Belajar Al-Quran Hadits di MAN 4 Pasaman Barat. Intiqad: Jurnal Agama Dan Pendidikan Islam, 12(2), 246255. https://doi.org/10.30596/intiqad.v12i2.4640 
Ansyah, S., Ritonga, M., \& Alrasi, F. (2020). Sistem Kaji Duduak Sebagai Strategi Pembelajaran Maharah Al-Qira'ah Di Madrasah Batang Kabung. Arabi : Journal of Arabic Studies, 5(2), 191. https://doi.org/10.24865/ajas. v5i2.257

Bakhtiar, M. I. (2015). Pengembangan Video Ice Breaking Sebagai Media Bimbingan Konseling Dalam Meningkatkan Keterampilan Sosial. Jurnal Psikologi Pendidikan Dan Konseling: Jurnal Kajian Psikologi Pendidikan Dan Bimbingan Konseling, 1(2), 150. https://doi.org/10.26858/jpkk.v1i2.1816

Deasy, C., Coughlan, B., Pironom, J., Jourdan, D., \& Mannix-McNamara, P. (2014). Psychological distress and coping amongst higher education students: A Mixed method enquiry. PLoS ONE, 9(12), 1-23. https://doi. org/10.1371/journal.pone.0115193

Di Monte, C., Monaco, S., Mariani, R., \& Di Trani, M. (2020). From Resilience to Burnout: Psychological Features of Italian General Practitioners During COVID-19 Emergency. Frontiers in Psychology, 11(October), 1-9. https://doi.org/10.3389/fpsyg.2020.567201

Fanani, A. (2017). Ice Breaking dalam Proses Belajar Mengajar. Jurnal Buana Pendidikan, VI(11), 1-7. https://doi.org/10.1145/3110292.3110316

Farwati, D. Z., Rahmah, M., \& Sutisna, E. (2018). the Application of Ice Breaking Activities in Teaching English To Junior High School Students. JETLi| Journal of English ..., 1(1), 1-10. https://journal.unpak.ac.id/ index.php/Jet-Li/article/view/1489

Halbesleben, J. R. B., \& Buckley, M. R. (2004). Burnout in organizational life. Journal of Management, 30(6), 859-879. https://doi.org/10.1016/j. jm.2004.06.004

Hutasoit, R., \& Tambunan, D. B. (2018). The Effect of Ice Breaking Technique in Teaching Speaking at the Tenth Grade Students of SMK Dharma Bhakti Siborongborong in Academic Year 2018/2019. International Journal of English Literature and Social Sciences, 3(5), 700-705. https://doi. org/10.22161/ijels.3.5.2

Islam, S., Baharun, H., Muali, C., Ghufron, M. I., Bali, M. el I., Wijaya, M., \& Marzuki, I. (2018). To Boost Students' Motivation and Achievement through Blended Learning. Journal of Physics: Conference Series, 1114(1), 1-11. https://doi.org/10.1088/1742-6596/1114/1/012046

Jandriఐ, P., Hayes, D., Truelove, I., Levinson, P., Mayo, P., Ryberg, T., \& Monzó, L. D. (2020). Teaching in the Age of Covid-19 Petar. Postdigital Science and 
Education, 2, 1069 -1230. https://doi.org/10.1007/s42438-020-00169-6

Khaira, M., Ritonga, M., \& Halim, S. (2021). The Effectiveness of Scrabble Game Media in Improving Learning Outcomes. Journal of Physics: Conference Series, 1933(1), 012128. https://doi.org/10.1088/17426596/1933/1/012128

Khairunnas, Ritonga, M., \& Lahmi, A. (2021). Pendididkan Agama Islam sebagai Basic Kedisiplinan: Studi Fenomenologi di SMP Negeri 3 Lembah Melintang Pasaman Barat. Al-Muaddib :Jurnal Ilmu-Ilmu Sosial Dan Keislaman, 6(1), 55-65. https://doi.org/10.31604/muaddib.v5i1.5565

Kintu, M. J., Zhu, C., \& Kagambe, E. (2017). Blended learning effectiveness: the relationship between student characteristics, design features and outcomes. International Journal of Educational Technology in Higher Education, 14(1), 1-20. https://doi.org/10.1186/s41239-017-0043-4

Licorish, S. A., Owen, H. E., Daniel, B., \& George, J. L. (2018). Students' perception of Kahoot!'s influence on teaching and learning. Research and Practice in Technology Enhanced Learning, 13(9), 1-24. https://doi. org/10.1186/s41039-018-0078-8

Mailita, Basyir, M. N., \& Abd, D. (2016). Upaya Guru Bimbingan Konseling dalam mencegah kejenuhan Belajar siswa di SMP Negeri Banda Aceh. Jurnal Ilmia Mahasiswa Bimbingan Dan Konseling, 1(2), 14-26.

Maslach, C., \& Jackson, S. E. (1981). The measurement of experienced burnout. Journal of Organizational Behavior, 2(2), 99-113. https://doi.org/10.1002/ job. 4030020205

Rachim, D. K. N. (2020). Study of The Lazy Nature of Physics Students Using The Quadratic Optimal Control Method. Jurnal Penelitian $\mathcal{E}$ Pengembangan Pendidikan Fisika, 6(2), 279-288. https://doi.org/10.21009/1.06214

Ritonga, M., Widodo, H., Munirah, \& Nurdianto, T. (2021). Arabic language learning reconstruction as a response to strengthen Al-Islam studies at higher education. International Journal of Evaluation and Research in Education, 10(1), 355-363. https://doi.org/10.11591/ijere.v10i1.20747

Sari, D. R., Rofiqo, N., Hartama, D., Windarto, A. P., \& Wanto, A. (2019). Analysis of the Factors Causing Lazy Students to Study Using the ELECTRE II Algorithm. The International Conference on Computer Science and Applied Mathematic, 1255(1), 1-7. https://doi.org/10.1088/1742$6596 / 1255 / 1 / 012007$ 
Sartika, F., Desriwita, E., \& Ritonga, M. (2020). Pemanfaatan Media Pembelajaran Dalam Meningkatkan Kualitas Pembelajaran PAI di Sekolah. Humanika, Kajian Ilmiah Mata Kuliah Umum, 20(2), 115-128. https://doi.org/10.21831/hum.v20i2.32598

Setiawaty, T., \& Tjahjono, G. (2019). Students Learning Difficulties and Saturation in Achieving Competency. Advances in Social Science, Education and Humanities Research, Volume 299 5th UPI International Conference on Technical and Vocational Education and Training (ICTVET 2018), January, 4-9. https://doi.org/10.2991/ictvet-18.2019.2

Sieberer-Nagler, K. (2016). Effective Classroom-Management \& Positive Teaching. English Language Teaching, 9(1), 163-172. https://doi. org/10.5539/elt.v9n1p163

Slivar, B. (2001). The syndrome of burnout, self-image, and anxiety with grammar school students. Psihološka Obzorja / Horizons of Psychology, 10(2), 21-32.

Solihat, A., Astuti, A. R., \& Satriani, I. (2020). the Influence of Ice Breaker To Students' Motivation in Teaching English. PROJECT (Professional Journal of English Education), 3(2), 210-216. https://doi.org/10.22460/project. v3i2.p210-216

Tongco, M. D. C. (2007). Purposive sampling as a tool for informant selection. Ethnobotany Research and Applications, 5, 147-158. https://doi. org/10.17348/era.5.0.147-158

Wullur, M. M., \& Werang, B. R. (2020). Emotional exhaustion and organizational commitment: Primary school teachers' perspective. International Journal of Evaluation and Research in Education, 9(4), 912-919. https://doi.org/10.11591/ijere.v9i4.20727

Yeganehpour, P. (2017). Ice-breaking as A Useful Teaching Policy for Both Genders. Journal of Education and Practice Www.Iiste.Org, 8(22), 137-142. https://www.researchgate.net/publication/326989361_Ice-breaking_ as_A_Useful_Teaching_Policy_for_Both_Gender

Yusuf, M., Ritonga, M., \& Mursal. (2020). Implementasi Karakter Disiplin dalam Kurikulum 2013 Pada Bidang Studi PAI di SMA Islam Terpadu Darul Hikmah. Jurnal Tarbiyatuna, 11(1), 49-60. 
Humanika, Kajian IImiah Mata Kuliah Umum, Vol. 21. No. 2. (2021), 113-128 